\title{
A case of a retained intralenticular foreign body for two years
}

This article was published in the following Dove Press journal:

Clinical Ophthalmology

I September 2010

Number of times this article has been viewed

\author{
Mete Güler' \\ Turgut Yilmaz ${ }^{2}$ \\ Mehmet Yiğit ${ }^{2}$ \\ Gülșen Ülkü ${ }^{2}$ \\ Sermal Arslan ${ }^{2}$ \\ 'Department of Ophthalmology, \\ Elazığ Harput State Hospital, Turkey; \\ ${ }^{2}$ Department of Ophthalmology, Elazığ \\ Education and Research Hospital, \\ Turkey
}

\begin{abstract}
We report a case of a missed metallic intraocular foreign body retained in the lens over a two-year period without causing inflammatory reaction, which presented with cataract later. A 24-year-old man presented with a progressive blurring of vision in the left eye for two years. He had had a history of metal-on-metal activity two years before. He had pain for one day in left eye and it was healed by the following day. Biomicroscopic examination revealed cataract, an intralenticular foreign body, and a corneal scar at seven o'clock meridian of the cornea in the left eye. Best-corrected visual acuity was 20/200 in the left eye. Intralenticular foreign body removal, phacoemulsification, and an intraocular lens implantation was performed under local anesthesia. The intralenticular foreign body was metallic and its size was about $2 \times 2 \mathrm{~mm}$. Two weeks after the operation best corrected visual acuity was 20/20 in left eye. A retained foreign body should be considered in each patient with a history of penetrating ocular trauma and all efforts must be made to exclude presumptive diagnosis of intraocular foreign body.
\end{abstract}

Keywords: cataract, intralenticular foreign body, penetrating intraocular injury

\section{Introduction}

Penetrating ocular trauma is an important cause of vision loss and may be associated with the presence of an intraocular foreign body (IOFB). Intraocular foreign bodies accompany $18 \%-41 \%$ of open globe injuries. ${ }^{1}$ But the lens is not commonly involved and intralenticular foreign bodies (ILFBs) constitute only approximately $5 \%-10 \%$ of all IOFBs. ${ }^{2}$ Intraocular foreign bodies resulting from penetrating ocular injuries are usually detected at the first visit. However a missed IOFB may present in different clinical aspects that may limit its detection, and symptoms may only become apparent after a prolonged period of time. ${ }^{3}$ We report a case of a missed metallic intraocular foreign body in the lens over a two-year period without causing severe inflammatory reaction and which presented with cataract later.

\section{Case}

A 24-year-old man presented with progressive blurring of vision in the left eye for two years. He had had a history of metal-on-metal activity two years before. He had pain for one day in left eye and it was healed by the following day. On presentation, his best-corrected visual acuities were 20/20 in the right eye and 20/200 in the left eye, respectively. The intraocular pressures were within normal limits. There was a corneal scar at seven o'clock meridian of the cornea in the left eye. After pupillary dilatation biomicroscopic examination revealed cataract and an intralenticular foreign body in the left eye (Figure 1). Fundus examination revealed no abnormality in
Correspondence: Mete Güler Department of Ophthalmology, Harput State Hospital, 23119 Elazığ, Turkey Tel +9004242181981

Fax+90 04242I 2146 I

Email meteglr@yahoo.com 


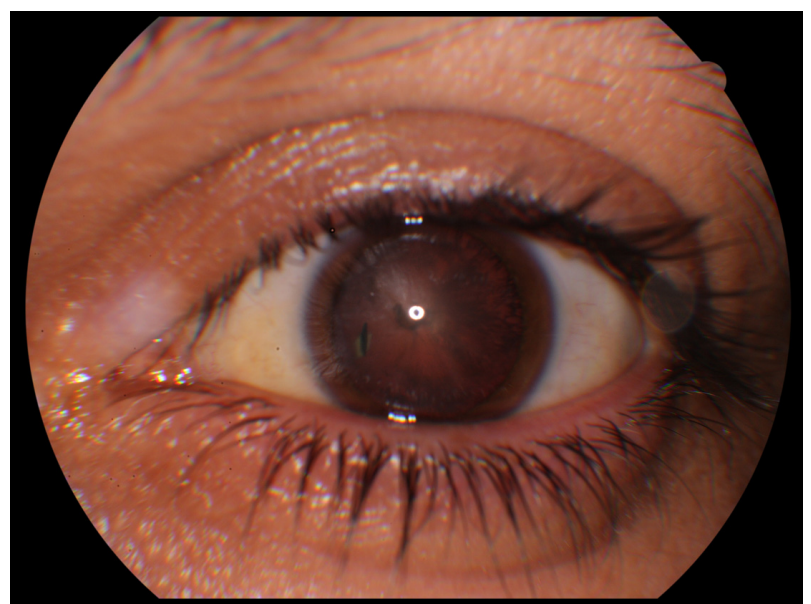

Figure I An intralenticular foreign body is seen in the seven o'clock meridian of the lens.

both eyes. After obtaining informed consent from patient, intralenticular foreign body removal, phacoemulsification and an intraocular lens (IOL) implantation was performed under local anesthesia. The IOFB was metallic and its size was about $2 \times 2 \mathrm{~mm}$ (Figure 2). Two weeks after the operation his best corrected visual acuities were 20/20 in both eyes.

\section{Discussion}

Intralenticular foreign bodies may be metallic or nonmetallic in nature. Nonmetallic ILFBs such as cilia, glass, stone, vegetable matter, and coal have been reported. When injured in this manner the lens has altered capsular integrity which results in the formation of a visually significant cataract. There is usually a minimal accompanying globe disruption but complications like uveitis, glaucoma, endophthalmitis, and intralenticular metallosis have been reported. ${ }^{4}$

Currently there are many tools available to aid in diagnosis of IOFBs, including plain X-ray, ultrasonography, optical coherens tomography, anterior segment optical coherence tomography (ASOCT), ultrasound biomicroscopy, computerized tomography (CT) scanning, and magnetic resonance imaging. Radiography is not an optimal diagnostic

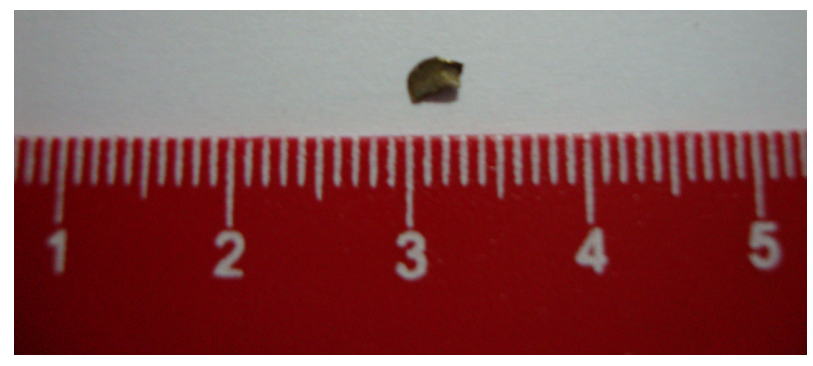

Figure 2 Foreign body removed from lens. It was about $2 \times 2 \mathrm{~mm}$ in size. technique because it cannot rule out the major percentage of IOFBs. Ultrasonography and CT are more sensitive methods to detect all kinds of IOFBs. ${ }^{5}$ Ultrasound biomicroscopy is a valuable adjunct in the evaluation of suspected ocular foreign bodies, especially involving small, nonmetallic, anteriorly located bodies that may not be detected by other methods. ${ }^{6}$ Magnetic resonance imaging can localize a nonmetallic IOFB, but is contraindicated in the case of metallic IOFBs and may produce motion artifacts. ${ }^{7}$ Optical coherence tomography and ASOCT are also helpful in establishing the localization and size of the foreign body. They have the added advantage of being noncontact. ${ }^{8}$

Our patient had an undetected ILFB for two years. He had corneal scarring caused by the foreign body which was selfsealed. He did not demonstrate any inflammatory reaction. Intralenticular foreign bodies, especially metallic in origin, can cause a severe inflammatory reaction (lens induced uveitis and metallosis). ${ }^{4}$ But certain intralenticular foreign bodies of inert material excite minimum inflammation and may remain quiescent for a long period. ${ }^{3}$ Our patient had a metallic foreign body but it may have been an alloy, the major constituent of which was relatively inert. On the other hand the healing capacity of the anterior lens capsule, in contrast to the posterior capsule, is well documented and is thought to result from the presence of the subcapsular epithelium. ${ }^{9}$ If the capsule defect is small, epithelial proliferation rapidly restores its continuity, limiting the free passage of ions and fluid that may result in progressive cataract formation. ${ }^{10}$ In our patient's case, the size of the ILFB was small and it is possible that the capsular break was small enough to heal spontaneously. The visual axis was not involved with the injured capsule or the foreign body. The reasons mentioned above may explain why the patient did not demonstrate any ocular discomfort for 2 years despite the presence of an ILFB.

Conservative management of ILFBs is an acceptable option unless ocular complications such as intraocular inflammation, cataract formation, or siderosis bulbi develop. ${ }^{11}$ If visual acuity is compromised by cataract formation induced by an ILFB, the standard management is removal of the foreign body, phacoemulsification, and IOL implantation (tri-combined operation). ${ }^{1} \mathrm{~A}$ retained foreign body should be considered in each patient with a history of penetrating ocular trauma and all efforts must be made to exclude presumptive diagnosis of IOFB.

\section{Disclosure}

The authors report no conflicts of interest in this work. 


\section{References}

1. Mester V, Kuhn F. Intraocular foreign bodies. Ophthalmol Clin North Am. 2002;15(2):235-242.

2. Coleman DJ, Lucas BC, Rondeau MJ, Chang S. Management of intraocular foreign bodies. Ophthalmology. 1987;94(12):1647-1653.

3. Omoti AE, Dawodu OA, Ogbeide OU. An unusual case of marble intraocular foreign body. Middle East Afr J Ophthalmol. 2008;15(1): 39-42.

4. Arora R, Sanga L, Kumar M, Taneja M. Intralenticular foreign bodies: report of eight cases and review of management . Indian J Ophthalmol. 2000;48(2):119-122.

5. Arnáiz J, Marco de Lucas E, Piedra T, et al. Intralenticular intraocular foreign body after stone impact: CT and US findings. Emerg Radiol. 2006;12(5):237-239.

6. Kaushik S, Ichhpujani P, Ramasubramanian A, Pandav SS. Occult intraocular foreign body: ultrasound biomicroscopy holds the key. Int Ophthalmol. 2006;28(1):71-73.
7. Lustrin ES, Brown JH, Novelline R, Weber AL. Radiologic assessment of trauma and foreign bodies of the eye and orbit. Neuroimag Clin North Am. 1996;6(1):219-237.

8. Wylegala E, Dobrowolski D, Nowińska A, Tarnawska D. Anterior segment optical coherence tomography in eye injuries. Graefes Arch Clin Exp Ophthalmol. 2009;247(4):451-455.

9. Fagerholm PP, Philipson BT. Experimental traumatic cataract. II. A transmission electron microscopy and extracellular tracer study. Invest Ophthalmol Vis Sci. 1979;18(11):1160-1171.

10. Chang YS, Jeong YC, Ko BY. A case of an asymptomatic intralenticular foreign body. Korean J Ophthalmol. 2008;22(4):272-275.

11. Lee LR, Briner AM. Intralenticular metallic foreign body. Aust $N Z J$ Ophthalmol. 1996;24(4):361-363.
Clinical Ophthalmology

\section{Publish your work in this journal}

Clinical Ophthalmology is an international, peer-reviewed journal covering all subspecialties within ophthalmology. Key topics include: Optometry; Visual science; Pharmacology and drug therapy in eye diseases; Basic Sciences; Primary and Secondary eye care; Patien Safety and Quality of Care Improvements. This journal is indexed on

Submit your manuscript here: http://www.dovepress.com/clinical-ophthalmology-journal

\section{Dovepress}

PubMed Central and CAS, and is the official journal of The Society of Clinical Ophthalmology (SCO). The manuscript management system is completely online and includes a very quick and fair peer-review system, which is all easy to use. Visit http://www.dovepress.com/ testimonials.php to read real quotes from published authors. 